DOI: $10.52950 / E S .2021 .10 .1 .002$

\title{
MANAGING PUBLIC DEBT: THE CASE OF SAUDI ARABIA
}

\section{BASSAM ALBASSAM}

\begin{abstract}
:
Managing public debt efficiently and effectively requires good management of public finances and a high quality of performance by financial and non-financial institutions in a given country. Likewise, the quality of a nation's economic and financial plans is an essential element in making the most of public debt and reducing the economic risk of default. This paper analyzes the levels of efficiency and effectiveness of public debt management in Saudi Arabia from 1991 to 2019 by looking at the relationship among the following variables: oil and non-oil revenues out of the total revenues, the current and capital expenditures of total expenditures, the ratio of deficit/surplus to GDP, and the general government's gross debt percentage of GDP. The outcome of the study suggests that the current system of managing the state's financial affairs and public debt might be not suitable for achieving the goals of the Saudi strategic plans. Therefore, the study calls for economic and financial policies to be developed to include all elements that affect the economy (e.g., governmental performance). The study also calls for the adoption of a long-term fiscal policy that does not change as state revenues increase and for the support of the implementation of the principles of good governance in the public finance system (e.g., strengthening public participation in the process of making the public budget and supporting the independence of the financial supervision agencies).
\end{abstract}

\section{Keywords:}

public finance; public debt; economic growth; Saudi Arabia

JEL Classification: E02, H00, E62

\section{Authors:}

BASSAM ALBASSAM, king saud university, Saudi Arabia, Email: balbassam1@ksu.edu.sa

\section{Citation:}

BASSAM ALBASSAM (2021). Managing Public Debt: The Case of Saudi Arabia. International Journal of Economic Sciences, Vol. X(1), pp. 20-38., 10.52950/ES.2021.10.1.002 
Saudi Arabia is a rentier state since more than $90 \%$ of it is income comes from natural resources (i.e., oil and gas). Consequently, any fluctuations in oil prices on the oil market causes problems for the country's long-term growth, which Saudi Arabia has tried to solve by adopting different strategic plans to diversify the nation's sources of income, starting in 1970s and including Vision 2030, which was first presented in 2016. Yet, none of these plans has been successful in diversifying the Saudi economy. Thus, to pay for increases in the amount of public expenditures and during times when the price of oil is low, the Saudi government must seek out loans, mainly from domestic financial institutions. For example, in 1999, the government's level of debt reached $102.99 \%$ of the country's GDP. However, in 2016, for the first time, the Saudi government took out loans from external financial institutions.

The main issue of this paper concerns how the Saudi government can manage and govern these loans. The goal of the study is to evaluate the progress that the Saudi economy has taken to diversify the economy including Saudi vision goals of having a stable economy away from heavily depend on oil revenues. In addition, introducing recommendations to reach the government strategic goals (e.g., sustainable development and public revenues diversification). Thus, this study discusses the effectiveness and efficiency of the Saudi government in managing its government debt since 1991. The main question is the following:

What is the relationship among the national debt and economic growth, current levels of public expenditures, and capital public expenditures in Saudi Arabia from 1991 to 2019?

The paper is organized as follows: first, it discusses the schools of thoughts regarding how to address public finance and governmental debt instruments. Next, the paper will take up how the Saudi economy deals with fluctuations in the price of oil, since this is the main source of national income. How best to manage the government debt of Saudi Arabia will be addressed next. The outcomes of the study and recommendations for how to best govern the Saudi public debt will be presented last.

\section{Public Finance and Government Debt Instruments}

Public demands for government services increase frequently, especially in developing countries where there is a high level of population growth, which results in greater pressures being put upon healthcare, education, and for creating additional jobs for citizens. For example, the MENA region is considered to have one of the highest rates in the world with a $2 \%$ growth in its population in 2019 (World Bank, 2020). Thus, governments there are under a greater amount of pressure to fund public programs to meet the public's demands. Schick (1998) argues that for many governments it is easier to spend more with the hope of attaining a greater amount of efficiency than to cut spending, and that this is why budget allocations globally have been increasing dramatically in recent years. Consequently, governments utilize tools and techniques to finance government projects and programs, including borrowing from domestic and external sources as part of their fiscal policy. Rich and poor countries do not differ in this way, despite the different levels of wealth among the countries and different levels of the governments' ability to commit to repaying their debts (Domar, 1944; Thompson, 2014). Hence, the cost of public debt is based on the economic and political risks that each country faces (Kamiguchi \& Tamai, 2019). 
Public expenditures increase frequently, which makes financing public services a challenge for many governments, regardless of their level of development and their GDP. Thus, using government debt instruments (e.g., loans and bonds) is a common tool for governments to take on deficits in the public budget. Several theories have discussed economic growth and its relation to government spending, including classical economic theory, Wagner's law, and Keynesian theory (Afonso, Schuknecht, \& Tanzi, 2005; Palley, 2013; Wijeweera \& Garis, 2009). The school of neoclassical economics argues that a balance of the public budget needs to be struck in the long term rather than the short term. On the other hand, Wagner's law argues that economic development provides the basis for economic growth, and that economic growth leads to an increase in governmental expenditures (Musgrave, 1959). By contrast, Classical economic theory argues that governments should have a limited role in stimulating economic growth and that markets perform better without governmental intervention. Thus, a government should operate under a balanced budget and have a limited amount of public debt (Palley, 2013). Alternatively, Keynesian theory supports direct governmental intervention in the economy. The theory is based on the principle that increases in government spending on infrastructure and social programs contributes to creating a more favorable environment for the private sector to invest, and thus it is better at creating jobs and supporting economic growth (Palley, 2013).

To summarize, the Keynesian model supports a greater amount of government spending on infrastructure and public programs in order to enhance economic growth and to increase in turn the private sector's contribution to GDP. This means that the government takes out a greater amount of loans and faces higher budget deficits. Since the 1930s, Keynesian theory has been the dominant model that most economies have used in managing public finances, especially for developing countries whose currencies are connected to one or more international currencies (i.e., a currency peg), which means that monetary policy will have a more limited role (Alesina \& Passalacqua, 2016; Kamiguchi \& Tamai, 2019; Thompson, 2014; Palley, 2013). Hence, in the case when there is a currency peg for an economy, fiscal policy will have the upper hand in running the country's economy since the country has no control over its own currency's exchange rate.

From the above, we could argue that the government's task is to make sure that the economy is growing and that the public services introduced to the public have a high quality, since financing these tasks requires a flow of funds that is not available all of the time, which makes debt instruments (e.g., loans and bounds) a favorable choice for countries (Najem \& Hetherington, 2003; Reinhart \& Rogoff, 2009). However, cutting spending is also a choice for reducing government spending, though governments tend to choose to borrow money instead in order to avoid political and economic instability (Casares, 2015; Domar, 1944; Schick, 1998). Consequently, debts need special attention from the government in managing and maintaining economic growth so that it can pay back its debt and the related interest on the debt.

\section{Government Debt Management- Global Phenomena}

Borrowing and issuing bonds have been the main sources of funding for most governments in the case of public budget deficits, rather than cutting spending (Ali \& Al Yahya, 2019; Feldstein, 1985; 
Schick, 1998). For example, in 2018, global debt reached US\$ 188 trillion (230\% of the global GDP), and in emerging and developing economies, the total debt climbed to an all-time high of US\$ 55 trillion (170\% of developing economies' GDP) (International Monetary Fund, 2020; Kose, Nagle, Ohnsorge, \& Sugawara, 2020). For example, as a percent of GDP, the Japan's debt reached 237.69\% in 2017, Sudan $207 \%$ in 2018, and Greece 176.64\% in 2018; Additionally, Emerging and Developing Economies (EMDE) averaged 170\% of the debt to GDP in 2019. In the case of Saudi Arabia, the General government gross debt as a percentage of GDP reached 23\% in 2018 (World Economic Outlook Database (WEOD) (2020); International Monetary Fund, 2020).

According to a study by the IMF (2020), debts have been rising as a result of a variety of economic and noneconomic crises, from which one can conclude that countries across the world have failed to have a plan in place to face crises that might come up. The absence of emergency plans, the low quality of financial policies, and the low quality of the governance process related to public funds are all reasons that have been mentioned for the rise in public debts worldwide (Badia \& Dudine, 2019; IMF, 2020; Kose et. al., 2020). It has also been argued that the issue of debt needs to be studied in terms of a long-term framework rather than over the short term, since borrowing as a tool for financing government expenditures has a long-term impact on the national income, tax rates, and economic growth (Domar, 1944; Kamiguchi \& Tamai, 2019).

Recently, the coronavirus pandemic has had an influence economically worldwide, and many countries have utilized one or more of debt instruments (issuing bonds or loans) to cover their additional costs. According to the IMF (2020), the total amount of emergency financing for 69 countries reached US\$24,726.75 million as of June 2020, and in the Middle East and Central Asia, 12 countries asked for loans from the IMF, which were approved in the amount of US\$ 7,048.83 million. In addition, developing countries' repayments of external debt (e.g., loans from financial institutions and bonds) is expected to range from US\$2.6 trillion to $\$ 3.4$ trillion in 2021 , mainly because of the coronavirus pandemic and related spending in terms of healthcare (UNCTD, 2020).

Whether or not to utilize debt instruments has long been debated by economists, political scientists, and politicians in terms of dealing with budget deficits. Saint-Paul (1992) argues that increasing the amount of public debt has a negative impact on economic growth in the long term, especially in cases where the levels of economic growth are unstable. Similarly, Gaber (2010) studied the influence of government borrowing in terms of dealing with the budget deficit and the so-called "crowding-out" effect, and analyzed the correlation between budget deficits and trade deficits worldwide after the financial crisis of 2008. The study showed that there is a positive influence of borrowing on economic growth and meeting public demand in the short-term. By contrast, Gaber (2010) finds that domestic borrowing might have a negative influence on private sector growth and on the capital markets because of the "crowding-out" effect that results from a high demand for loans from the government, which makes private sector borrowing more expensive in terms of higher interest rates for loans.

Many studies on the topic of public debt have argued that the impact of public debt on the economy should be analyzed in the long term and not in the short term (Lartey, Musah, Okyere, \& Yusif, 2018; Ncanywa \& Masoga, 2018; Yusuf \& Said, 2018). Moreover, studies on public debt have differentiated between domestic loans (those from financial institutions in the country or 
government bonds held in the local market) and external loans (those from financial institutions outside of the country or government bonds held in the global market). It has been argued that domestic loans have a negative effect on the economy and private sector growth because of the "crowding-out" effect, while external debts come with high rates and sometimes political pressure that is put upon the countries receiving the loans (Adam \& Bevan, 2005; Casares, 2015; Thompson, 2014).

From the above, it is clear that obtaining loans is not a problem in itself. Rather what needs to a priority in political and economic discussions is how these loans are dispersed. In addition, taking on external and domestic debt has an effect on economic growth. In most developing countries, the majority of loans come from international financial institutions or from government bonds in the global market (external debt), where the economic risk is higher. Thus, supporting the institutional quality of the government's work and adopting good governance practices for public financial management (e.g., budgetary transparency, fighting government corruption, and maintaining the rule of law) are said by many studies to be important factors in utilizing loans for the sake of better economic growth (Alesina \& Passalacqua, 2016; Ali \& AlYahya, 2019; Gollwitzer, 2010; Kose et. al., 2020).

However, many studies have been conducted regarding managing debt in Saudi Arabia, this study concentrates on analyzing public debt in Saudi Arabia as part of Saudi Vision 2030 and corona pandemic. In addition, Saudi Arabia has been adopting many plans since 1970 to diversify the economy, where such goal has not been reached yet; hence, the Saudi economy depends heavily on income from oil revenues. These plans have been funded by public debts (e.g., loans and issuing bonds), especially when the price of oil goes down. Thus, introducing recommendations as the outcome of this paper, help the Saudi government to manage public debt and utilize it efficiently and effectively.

\section{Managing Public Debt: The Case of Saudi Arabia}

The Saudi economy depends heavily on income from natural resources, such as oil and natural gas. As a result, the Saudi economy is very sensitive to fluctuations in the price of oil. In 2018, oil revenue accounted for $68 \%$ of the total revenue in Saudi Arabia (constant prices). In addition, in 2018, the oil sector accounted for $43.24 \%$ of the Saudi GDP while the governmental sector accounted for $16.87 \%$ of GDP and the private sector accounted for $39.32 \%$ of GDP (SAMA, 2020; World Economic Forum, 2019). The private sector's contribution to the GDP was low when compared to the other G-20 nations. For example, the domestic credit to the private sector as a percentage of GDP in 2018 was the following: Saudi Arabia, 54\%; the Middle East and North Africa (MENA), 54.7\%; Euro Area, 86.8\%; the United States, 186\%; OECD members, 141.6\%; and, the world average, $128.61 \%$ (World Bank, 2019).

Rentier states (e.g., Saudi Arabia), in which the nation's wealth is primarily generated from natural resources, often suffer from the so-called "resource curse," which is defined as "a complex phenomenon in which, through several economic, institutional, and political economy transmission mechanisms, resource abundance may translate into stagnation, waste, and conflict" (Hélis \& Dabán-Sánchez, 2010, p. 9). Accordingly, many studies have found that 
developing countries with high-quality institutions and well-managed public financial systems were more resistant to crises and recovered more quickly when compared to other economies (Auty \& Gelb, 2001; Aina, Wafer, Ahmed \& Alshuwaikhat, 2019; Mauro et al., 2009; Hélis \& Dabán-Sánchez, 2010). Thus, being a rentier state, combined with its affliction with the resource curse, has had an influence on the ability to achieve sustainable economic growth in Saudi Arabia.

From Figure 1, we can see that there is a trend in borrowing a greater amount of money to finance the budget deficit (this deficit resulted from the low price of oil). It is important to mention here that the launch of the Saudi Vision 2030 in April, 2016 came with a projection that there would be an increase in the public debt to about 29\% of GDP in 2020 and that the public budget would be balanced (that is, have no deficit) by 2023 (Saudi Vision 2030, 2018). It was not until 2015, when the Saudi government decided to use external lenders (e.g., in 2019, 45.54\% of the total public debt was external) (SAMA, 2020). This new move from Saudi Arabia to use external sources along with internal sources in financing the public debt, came to avoid drying fiscal liquidity in the economy, limiting the negative effect of "crowding-out" the private sector through competing in getting loans, and attracting investors - especially financial institutions - to the Saudi market as part of the Saudi vision 2030 (Beidas-Strom \& Lorusso, 2019; Badia \& Dudine, 2019; Kose et al., 2020; Ministry of Finance- Saudi Arabia, 2020; Saudi Vision 2030, 2018)

\section{Figure 1. The Public Debt in Saudi Arabia 2005-2018}

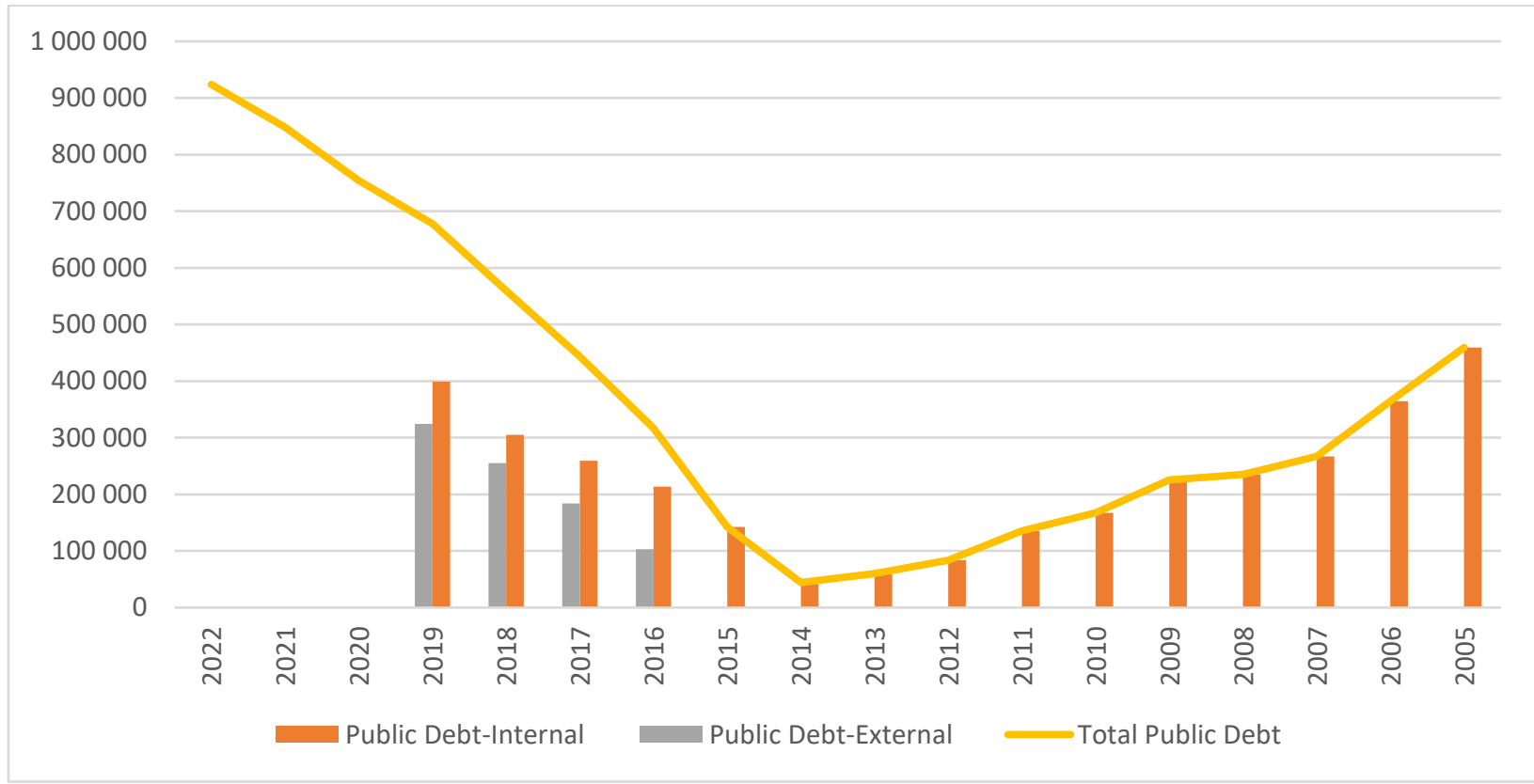

Source: SAMA (2020)

Note: Million Riyals (1 SAR = 3.75 USD); Years 2020-2022 estimation.

After the arrival of the coronavirus pandemic, many countries, including Saudi Arabia, made changes in the forecasts for their countries' revenues and have worked hard to control their public expenditures. Thus, Saudi Arabia announced cuts in some spending and delays for some of its big projects, which will have an impact on the government's plans the achieve a balanced budget 
by 2023 . Since the beginning of 2020 , the government has cut public spending (e.g., $66 \%$ of subsidies and $25 \%$ of social benefits), though the pandemic will still have an impact on its plans for borrowing (the government announced that the public debt could reach $50 \%$ of GDP by the end of 2020) (Ministry of Finance-Saudi Arabia, 2020). Additionally, the government's reserve is used by the government to finance the deficit for its public budget. In 2014, the government reserve reached US $\$ 744.44$ billion. However, this declined to reach US $\$ 467$ billion in 2019 (Ministry of Finance-Saudi Arabia, 2020), and is expected to go lower in terms of financing the deficit of the public budget in 2020. From these numbers, it's clear that the government has used many tools to finance the deficit in the public budget, whether borrowing, or withdrawing from the government reserve, or, to a lesser extent, making cuts in spending. Thus, we could argue that not adopting a clear and specific fiscal policy during the past several years and having a lack of clarity to its plans to deal with emergencies and crises has resulted in less economic stability and has contributed to not achieving the economic goals of the national plans put in place since 1970 (Aldukheil, 2017; Beidas-Strom \& Lorusso, 2019).

In addition, Saudi Arabia's low level of performance in many indicators related to public financial management and governance (e.g., governance quality and budgetary transparency) illustrates the importance of having a comprehensive view of reform, since such reforms needs to include administrative, social, and economic reforms if a country is to reach long-term economic growth and a sustainable level of development. Moreover, these indicators help us to understand the financial behavior related to the country's fiscal policy. One of these indicators is the Open Budget Index, which is a product of the International Budget Partnership's Open Budget Initiative, "a global research and advocacy program to promote public access to budget information and the adoption of accountable budget systems" (International Budget Partnership [IBP], 2020). According to the Open Budget Index, Saudi Arabia scores very low in all categories of the open budget survey (including budgetary transparency, public participation, and budget oversight). However, in the 2019 report, Saudi Arabia saw some improvement by scoring 18/100 in the budgetary transparency category (the global average was 45) and 11/100 (weak) (the global average was 14) in budgetary oversight (including legislative oversight and audit oversight), though it still scored zero in public participation (IBP, 2020). Thus, we could argue that the development needed urgently in the public budgetary process needs to have a more efficient and effective technique for utilizing the public funds and for limiting corruption and the waste of public money.

One of the main themes of all of the Saudi government's strategic plans since 1970 has been improving the level of public sector productivity. Hence, the public sector is the main player in the social and economic aspects of Saudi Arabia, though there is a very limited amount of public participation in running the state's affairs and there is a small contribution made by the nongovernmental sectors (e.g., private and not-for-profit sectors) in the economy. Thus, the government has the upper hand in designing public policies, implementing them, and controlling their implementation (Aldukheil, 2017; Najem \& Hetherington, 2003; Ramady, 2010). Table 2 shows the performance of Saudi Arabia in terms of the six Worldwide Governance Indicators (WGI), introduced by Kaufmann et al. (2009), which have been adopted by policymakers and researchers worldwide to evaluate the quality of a country's governance (Arndt \& Oman, 2006; Apaza, 2009; Langbein \& Knack, 2010). These six factors include 1) the control of corruption 
(CC), 2) governmental effectiveness (GE), 3) political stability and the absence of violence/terrorism $(P V), 4)$ regulatory quality $(R Q), 5)$ the rule of law $(R L)$, and 6) voice and accountability (VA) (see Table 2). The WGI uses 31 sources to measure these indicators, and each indicator concentrates on measuring one aspect of the governance process. In addition, the WGI uses an aggregate methodology to construct the indicators. The indicators have been structured using many data sources, such as surveys and reports (Kaufmann et al., 2010; World Bank, 2018).

By looking at the performance of Saudi Arabia in the governance indicators, we can see that public participation and accountability (VA) are scored the lowest among all of the other factors for all years. In 2018, Saudi Arabia was in the 5.9/100 percentile rank compared to the rest of the world in VA. Similarly, political stability and the absence of violence (PS) ranked 28.6/100 in 2018. By contrast, governmental productivity and the quality of governmental outcomes (GE), fighting corruption (CC), quality of regulations (RQ), and implementing copyrights (RL) are all above 50/100 when compared to other countries (World Bank, 2019). From these numbers, we can argue that these numbers have been steady, especially for $R Q, R L, C C$, and $G E$, over the years. Yet, this stability has not been connected to any increase in public participation or greater protection for copyright. Many explanations have been introduced to explain this, including there being a gap between the approval of legislation and implementing it, the lack of oversight by NGOs of government work, and the limited participation of beneficiaries (individuals and the private sector) in running the state's affairs (Aldukheil, 2017; Alkadry, 2015; Najem \& Hetherington, 2003; Ramady, 2010).

The performance of Saudi Arabia in the WGI could be connected to the way the government manages its public debts. Public debts are considered to be an income to a country that comes with a burden to repay the debt. Thus, governmental effectiveness is a crucial element for: utilizing the funds that come from the debt, controlling corruption, limiting the waste of public money, enhancing the quality of fiscal laws and regulations, supporting economic growth, and enhancing the wellbeing of the country's people (IBP, 2020; Joharji \& Willoughby, 2014).

\section{Related Research}

Managing public finances efficiently and effectively is the collective work of many governmental agencies, including the legislative branch, which issues and approves regulations and laws; the executive branch, which adopts these plans and executes them; and oversight institutions (e.g., NGOs) that seek to control government spending and limit the waste of public funds (Kose et al., 2020; Montes et al., 2019). In addition, a greater amount of public debt has an effect on borrower countries, whether they are developing or developed, in the form of increases in taxes and fees (Dotsey, 1994; Barro, 1979), higher interest rates (Baldacci \& Kumar, 2010; Gale \& Orszag, 2002), higher rates of inflation over the long run (Cochrane, 2011; Barro, 1995), a more limited amount of public capital spending (Aizenman et al., 2007; Mahmah \& Kandil, 2019), and a greater amount of fiscal policy uncertainty (Mahmah \& Kandil, 2019; Kumar \& Woo, 2009). Moreover, wealthier countries (e.g., natural resource-based economies [i.e., oil- and gas-based economies]) face challenges in utilizing the income they get from natural resources since there can be a great 
amount of fluctuation in gas and oil prices, which makes them seek out loans (through direct borrowing or issuing government bonds) when there is a deficit in the public budget. Thus, managing the public debt is a challenge in particular for developing countries and transitioning economies that have a lack of an efficient and effective public financial management system (Kose et al., 2020; Montes et al., 2019).

One of the controversial issues related to the Saudi public budget is the steady increase of its public expenditures given that oil revenues are the main source of its income (Al-Qudair, 2005). Additionally, limiting spending in terms of social subsidies, increasing fees, and issuing new taxes are tools that have been used by the government to fill in the gap of the public budget deficit. Consequently, the wellbeing and purchasing power of the Saudi people decreases during times of crises because of the added taxes and fees, which also have a negative impact on economic growth (Al-Qudair, 2005; Beidas-Strom \& Lorusso, 2019; Muye, Kaita, \& Hassan, 2017). In addition, the public debt has an impact on Saudi Arabia both financially and economically. The impact is financial because taking on national debt crowds out the private sector in the demand for domestic loans, especially in times of crisis when companies need loans to be able to pass through difficult times. The impact is also economic, since many big projects are postponed during crises. According to Al-Qudair (2005), the relationship between government expenditures and revenues "might complicate the government's efforts to control the budget deficit and may contribute in explaining the high national debt figure" (p. 40).

Saudi Arabia is going through public financial management reforms as part of Vision 2030, including putting in place a "financial sector development program" and a "fiscal balance program." These programs are to introduce reforms to public financing and aim to reach a balanced budget by 2030 (Saudi Vision 2030, 2018). However, this is not the first attempt of reform the public finance system in Saudi Arabia. For example, in 2000, the government introduced a plan to attract investment in the economy by reforming its budgetary structure and directing more spending to its infrastructure. Yet, many studies argue that what is missing in all of these government plans is the adoption of long-term fiscal and monetary policies and the application of good governance practices to the public budget (e.g., increase the amount of public participation and enhance governmental accountability) (Aldukheil, 2017; Joharji \& Willoughby, 2014; Najem \& Hetherington, 2003; Thompson, 2014).

As noted above, whenever the price of oil goes down, the government faces budget deficits and seeks to obtain loans. Mirzoev et al. (2020) argue that all Arab state countries in the Gulf (GCC), including Saudi Arabia, have adopted fiscal and monetary reforms to diversify their economies and to be less dependent on oil. But, they note, these countries did not implement the fundamental changes needed to reach fiscal sustainability. Thus, they argue that the GCC countries must find ways to benefit from the wealth they have accrued over the years to build more diverse economies by developing better budgetary processes. They also recommend controlling government expenses and applying efficient methods to the budgetary process as among the best means for attaining fiscal sustainability. Accordingly, long-term economic growth that is based on a longterm plan is the best recipe; where "faster economic diversification will not resolve the fiscal challenge on its own and countries will also need to increase their non-oil fiscal revenue" (Mirzoev et al., 2020, p. 30). 
The quality of public financial management (PFM) is important for reaching higher levels of diversity, poverty reduction, and the control of corruption in public finance (Pretorius \& Pretorius, 2009). In addition, PFM can maximize the efficiency of the public budget and achieve economic and social sustainability (Feldstein, 1985; Ncanywa \& Masoga, 2018). In a comparison among the United Kingdom, Russia, and Saudi Arabia in dealing with oil shocks, a study by Beidas-Strom and Lorusso (2019) found that the level of economic diversification benefited the economy in facing economic crises (e.g., when the price of oil dropped). In addition, the stability of monetary and fiscal policies and the productivity of the public sector are important keys for managing well the economy and the public debt during times of crisis. Therefore, the study found that integrating a structural reform of public policy, especially those related to fiscal policy, has to be one of the main tasks of the Saudi government on the road of economic diversification and economic stability. The main challenge in doing so, the study noted, is "to ensure that sound macroeconomic policies continue to be implemented and structural policies that have led to resource misallocation are rebalanced to raise potential output while being mindful of equity considerations" (BeidasStrom \& Lorusso, 2019, p. 2).

Public spending on projects and programs needs to be transparent and follow a strategic national plan put in place to serve the targeted goals set by the government, especially if these programs are to be funded by loans (Montes et al., 2019). In addition, adopting accountability and responsibility factors in minimizing the amount of waste in public spending and in fighting corruption are necessary steps to be taken by governments and NGOs to support long-term economic growth and the wellbeing of the people (Kose et al., 2020). Arjomand, Emami, and Salimi (2016) studied the influence of the budget deficit on economic growth and inflation in the Middle East and North Africa (MENA) from 2000 to 2013 (Saudi Arabia is part of MENA region). The result showed that having an efficient budgetary system has an impact on economic growth and the outcomes of public programs. Moreover, in almost all cases, the budget deficits financed in MENA countries through loans and borrowing from the central bank contributed to raising the national debt, which led to a rise in interest rates on loans to individuals and in the private sector, which in turn resulted in slower economic growth and a higher inflation rate. Thus, the study concluded that governments need to not rely solely on borrowing when they face budget deficits. Rather governments need to adopt proper fiscal and monetary policies and cut unnecessary public spending, and in cases where they must take out loans, the funds derived should be directed to capital spending (Arjomand et al., 2016).

Based on the literature review, we can argue that regardless of many economic plans and public finance reforms, the Saudi economy has yet to be diversified, yet to maintain a stable level of public spending, and yet to enhance its non-oil revenues. Having a long-term fiscal plan, applying good governance practices (e.g., increasing public participation and increasing the level of governmental accountability), better managing the budgetary process and public expenditures, and diversifying the economy away from oil are all key elements recommended by the studies to be put in place before any plan for reforms to public finances can be successful. However, many of the Saudi Vision 2030 outcomes have yet to be seen, and many studies have argued that the lack of including the above-mentioned elements puts Vision 2030 in danger of not reaching its goals. The first test for Vision 2030 was the coronavirus pandemic. However, all countries around the globe are suffering from the effects of the crisis, with the Saudi economy facing particular 
challenges in continuing to finance fundamental projects (e.g., the Riyadh metro and the NEOM project) (Ministry of Finance, 2020). In addition, the government withdraw from its reserve and issued bonds to finance the public budget deficit (Kose et al., 2020; Ministry of Finance, 2020), which requires further reevaluating the process of managing the public funds.

\section{Methodology and Analysis}

Although it is too early to address the impact of the coronavirus pandemic on the Saudi economy, the following section will address the efficiency and effectiveness of managing the Saudi public debt from 1991 to 2019 so that we can better understand the public debt management system and analyze the government's behavior in dealing with funds from borrowing and issuing bonds. The main research question of this paper is the following:

What is the relationship among the national debt and economic growth, the current levels of public expenditure, and capital public expenditures in Saudi Arabia from 1991 to 2019?

Thus, we will analyze secondary data taken from the Saudi Arabian Monetary Fund (SAMA) and the World Bank in order to answer quantitatively and qualitatively the research question.

To begin answering the research question, let's look at Figure 2, which shows Saudi Arabia's public finances from 1991 to 2019, including its oil revenues as a percentage of total revenues, other revenues as a percentage of total revenues, current expenditures as a percentage of total expenditures, the capital expenditure's percentage of total expenditures, the ratio of deficit/surplus to GDP, and the general government's gross debt/percentage of GDP. The relationship among these factors is important for understanding the way the public debt is managed, and this helps us to visualize the public finance behavior of Saudi Arabia. In this figure, a ratio of the factors related to public finance are given as a percentage of GDP and has been presented to have a better understanding of the relationship between public debt and government expenditures and revenues. Moreover, the general government's gross debt/percentage of GDP "consists of all liabilities that require payment or payments of interest and/or principal by the debtor to the creditor at a date or dates in the future" (IMF, 2020).

In answering the research question, from the figure we can see that there is an inverse relationship between oil revenues and public debt, that is, whenever there is a high amount of income from oil, there is no need for the government to borrow money. Accordingly, there is no significant impact from the other revenues considering their small percentage on the change in GDP. In addition, this relationship shows that there has been no real amount of economic diversification, which makes the economy vulnerable to facing economic and noneconomic crises. Similarly, the public budget deficit (i.e., the ratio of the deficit/surplus to GDP) gap has been filled by borrowing money. For example, in 1999, the percentage of public debt was $102.99 \%$ of GDP to cover the lower amount of oil revenue in 1998 (56.49\%), and, in 2011, oil revenues were $92.56 \%$ of GDP and the public debt was $5.38 \%$. Thus, government debt instruments, rather than cuts to public spending, play a critical role in financing the public budget deficit.

Managing public expenditures has been the main challenge for Saudi Arabian economy because of the diversity of expenditures and the increasing demands of the public. In answering the 
research question, from figure 2 we can see the current expenditures grow and the capital expenditures slow down when public debt goes up in Saudi Arabia. For example, in 1997, the capital projects (e.g., infrastructure) were almost at zero at the same time as the public debt was increasing. In addition, in 2016, the public debt started to rise and the capital expenditures started to decrease while current expenditures increased. Thus, we could argue that financing for current expenditures comes in part from the public debt (e.g., borrowing and issuing bonds), which is considered a short-term plan for utilizing the fund; and when the oil income starts to follow the share of capital expenditures of GDP increases. Hence, not directing public debt to capital investment reduces the ability of the economy to diversify (Al-Qudair, 2005; Mahmah \& Kandil, 2019). In addition, many studies have argued that maintaining a sustainable level of economic growth requires the good management of public finances, including the public debt, by building a strong economy that can face crises (Aizenman et al., 2007; Casares, 2015) and support the wellbeing of the people (Beidas-Strom, \& Lorusso, 2019; Kamiguchi \& Tamai, 2019), all while knowing that during crises it is easy to see a high amount of public debt due to social programs and an increase taxes and fees, which negatively effects the purchasing power of individuals and impacts the economic growth rate.

However, it is hard to draw a clear relationship between public debt and economic diversification in Saudi Arabia since other factors influence the process of diversification, making frequent changes in fiscal policy will undesirably influence government plans to attract domestic and international investors. Also, Saudi Arabia has long made plans for development and diversifying its economy beyond oil income-its first major plan was in 1970 and it is currently applying Vision 2030, which was put in place in 2016 - however, from the data available, it seems that the goals of all of them have yet to be met. 


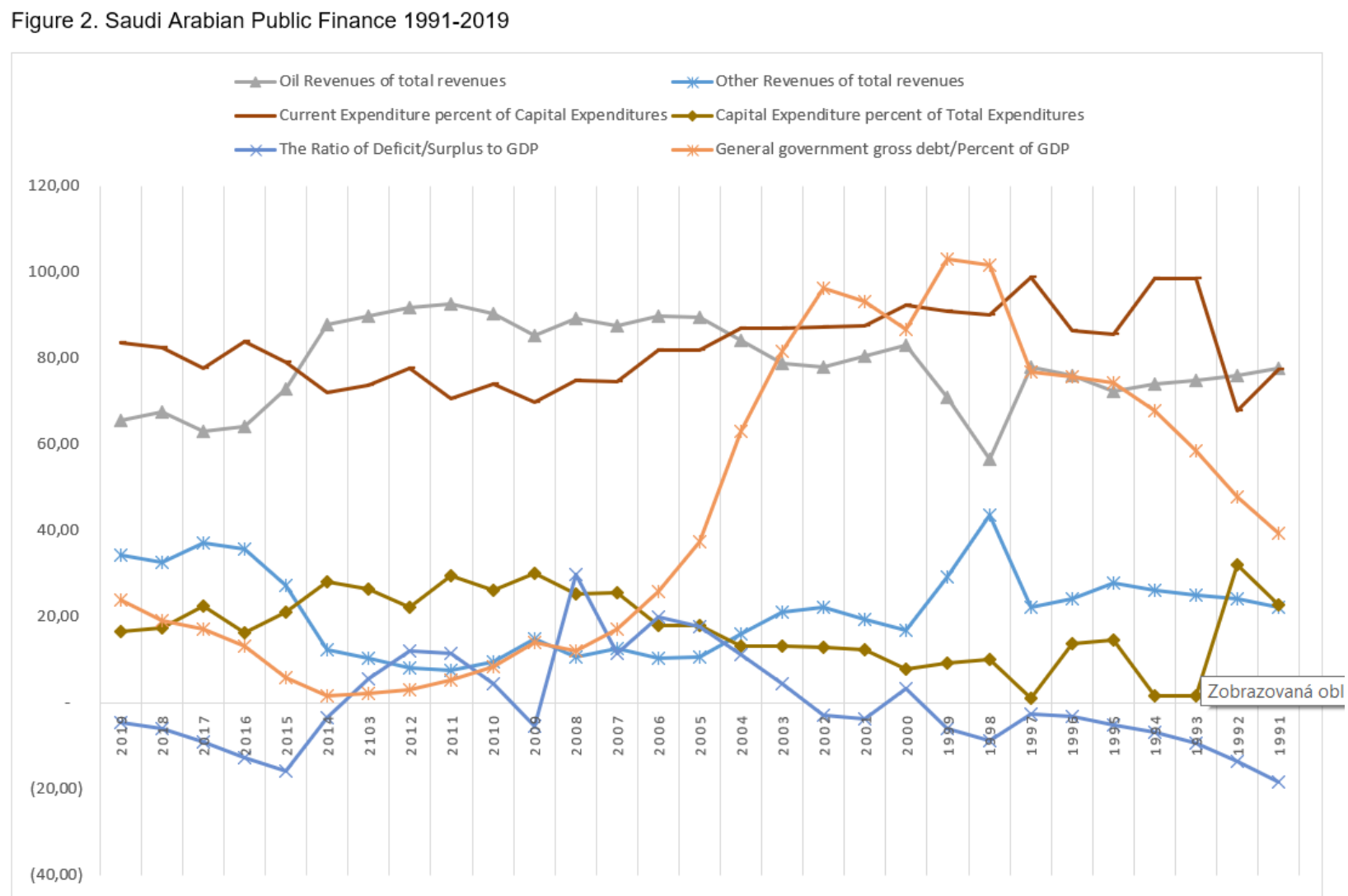

Sources: SAMA (2020); The World Bank (2019)

\section{Results and Policy Implications}

Natural resource-based economies (e.g., Saudi Arabia, Qatar, and Kuwait) use debt instruments to fill the gap between public revenues and public spending, when they should utilize their high amount of oil income to build long-term growth. In other words, they have taken out loans when they have faced budget deficits during times when there was a low price for oil and have repaid their debt when the price of oil went back up, with almost no real fiscal plans in place (Aldukheil, 2017; Beidas-Strom \& Lorusso, 2019; Muye et al., 2017). Accordingly, many studies and reports criticized these natural resource-based economies for not building stronger economies during times when they had a high level of income from oil and gas. Most of public spending during these times seems to go to current expenditures rather than capital spending, and thus they have failed to build a better knowledge management transfer system to reach a higher level of economic diversification (Albassam, 2019; Arjomand et. al., 2016; Mahmah \& Kandil, 2019; Mirzoev et al., 2020).

However, since the economic outcomes from the coronavirus pandemic has yet to be fully felt, this study concentrates more on the behavior of Saudi Arabia in managing its public debts for almost thirty years, and this will help us to understand the public debt management style of the country. The analysis from the literature review and the data show that Saudi Arabia seeks out loans and issues bonds during times of crisis and when it faces a public budget deficit. This financial behavior is common among governments in developing countries during times of crisis, 
when most of the government debt goes to pay for current expenditures (e.g., wages and allowances) for public employees and most of the capital expenditures (e.g., for infrastructure and the metro) are postponed. Similarly, during non-crisis times (when the oil price has gone up), the government did not use these revenues to build a knowledge-based economy, promote the benefits to be gained from the comparative advantage of the Saudi economy (e.g., agriculture), or build up its expertise in the oil industry given that the Kingdom is one of the largest producers of oil and gas.

In addition, despite putting in place strategic plans from 1970 to, most recently, 2016 in terms of its Vision 2030 for public sector and public finance reforms, the economy has not yet reached the main objectives of these plans to diversify the Saudi economy and its sources of income. Several reasons have been mentioned in this paper as reasons for this lack of results. First, the performance of Saudi Arabia in terms of governance indicators is low, especially for governmental effectiveness, controlling corruption, and governmental accountability. Hence, providing for more effective and efficient governmental outcomes is critical in managing funds from public debt and limiting public waste. In addition, the public and NGOs are not able to really participate in designing or implementing public policies (e.g., fiscal policies), and have no oversight of the public finance system (e.g., public budget process). The limited role given to the Saudi public has resulted in the low quality of the budgetary process and public financial system in Saudi Arabia. The study also notes that there has been a lack of stability in the plans and policies of the Saudi government, whether this is due to a changes in preparing and implementing the plans, or because of drops in the oil price, or because of a shortage of funds. This unsteadiness of policies has led to poor results and an increase in costs due to the constant changes in strategic plans.

From the above, it is clear that there is a need to make fundamental changes in the mechanism for preparing and implementing the country's fiscal plans in order to benefit from larger revenues in times of prosperity and to achieve real economic development. In addition, when public debt is needed, the funding from the debt needs to be directed to strategic programs and infrastructure projects, and these projects need to be managed according to a long-term investment plan even during times of crisis. Using debt to finance public programs and projects is a common practice and sometimes this is a country's best option. However, when there is a lack of good debt management and there is an inefficiency in governing public money, there is a greater likelihood that the debt will be a burden for future generations, especially in developing countries that suffer from a low quality of governance. In oil-rich countries like Saudi Arabia, the government should adopt policies and emergency plans for when there are fluctuations in oil prices, especially given that there is a global trend toward taking up alternative and renewable energy in the pursuit of reducing the pollution levels caused by oil consumption.

\section{Conclusion}

Managing public debt is a difficult task for governments, especially developing countries, given the low level of good governance practices in these countries. Although the use of public debt instruments is common among these countries, the management of these instruments and their use in promoting economic development are among the challenges that these countries face. As 
a result of their low level of governmental transparency, the absence of the application of accountability principles, and the poor quality of their public fiscal policies, these governments face additional burdens in terms of repaying their debts. This burden does not just affect the government, but also affects the citizens and the private sector since government borrowing results in a higher cost of financing and there is often the imposition of taxes and fees to pay off the debt and its interest.

A major challenge for the Saudi government to achieve the goals of the strategic plans under the current system is to manage the state's financial affairs. Moreover, good management of the public debt and the national income is an essential element for making the most out of the public debt without negatively affecting the purchasing power of individuals and impacting economic growth. The current study concludes that the low quality of the long-term fiscal plan and the absence of having in place an emergency plan are among the reasons for the lack of good management of public finances and the public debt. Although high oil prices (i.e., high revenues) is an essential component for reducing the level of public debt, the absence of economic diversification makes the economy hostage to any fluctuations in oil prices.

This study recommends strengthening the principles of financial accountability, increasing the participation of the private sector and individuals in designing the financial policies of the country, and allowing the public to monitor policy implementation. Also, this study argues that the government needs to benefit more when it has a greater amount of revenues in terms of building a stronger economy that will be less effected by crises and will be able to keep government debts to a minimum. Likewise, any use of the public debt should be directed to capital expenditures, not current ones. Consequently, debt instruments should be used for large public investments and infrastructure projects.

The subject of public debt management is one of the most debated issues when looking at developing economies. Future research could be extended to cover the time period related to the coronavirus pandemic. In addition, future research should look to gauge the social impact of the public debt in Saudi Arabia.

\section{References}

Adam, C.S. and D.L. Bevan. (2005). Fiscal Deficits and Growth in Developing Countries, Journal of Public Economics, 89 (1), pp. 571-597.

Afonso, A., Schuknecht, L., \& Tanzi, V. (2005). Public sector efficiency: an international comparison. Public choice, 123(3-4), pp. 321-347. DOI: 10.1007/s11127-005-7165-2

Aina, Y. A., Wafer, A., Ahmed, F., \& Alshuwaikhat, H. M. (2019). Top-down sustainable urban development? Urban governance transformation in Saudi Arabia. Cities, 90 (1), pp. 272-281. DOI: 10.1016/j.cities.2019.03.003

Aizenman, J., Kletzer, K., Pinto, B. (2007), Economic Growth with Constraints on Tax Revenues and Public Debt: Implications for Fiscal Policy and Cross-Country Differences. National Bureau of Economic Research Working Paper Series. No. 12750. DOI: 10.3386/w12750.

Albassam, B. A. (2019). Building an effective knowledge management system in Saudi Arabia using the principles of good governance. Resources Policy, 64 (1), pp. 1-8. DOI: 10.1016/j.resourpol.2019.101531 
Aldukheil, A. (2017). The Saudi Economy: before and after Vision 2030. Beirut, Lebanon. Dar Alsaqi.

Alesina, A., \& Passalacqua, A. (2016). The political economy of government debt. In Handbook of macroeconomics (Vol. 2, pp. 2599-2651). Elsevier. DOI: 10.1016/bs.hesmac.2016.03.014

Ali, T., \& AlYahya, B. (2019). The effect of governance on public debt: an empirical investigation for the Arabian Gulf countries. Journal of Economic Studies, 46(4), pp. 812-841. DOI: 10.1108/JES-072017-0168

Alkadry, M. (2015). Saudi Arabia and the Mirage of Decentralization. In Dawoody, A (Eds.). Public Administration and Policy in the Middle East, (pp. 173-188). Springer: New York, USA.

Al-Qudair, K. H. (2005). The relationship between government expenditure and revenues in the Kingdom of Saudi Arabia: Testing for cointegration and causality. Economics and Administration, 19(1), 3143.

Apaza, C. (2009). Measuring governance and corruption through the worldwide governance indicators: Critiques, responses, and ongoing scholarly discussion. PS: Political Science \& Politics, 42 (1), pp. 139-143. DOI: $10.1017 /$ S1049096509090106

Arjomand, M., Emami, K., \& Salimi, F. (2016). Growth and Productivity; the role of budget deficit in the MENA selected countries. Procedia Economics and Finance, 36 (1), pp. 345-352. DOI: $10.1016 / \mathrm{S} 2212-5671(16) 30046-6$

Arndt, C. \& Oman, C. (2006). Uses and Abuses of Governance Indicators. Paris, France: Development Centre Studies, OECD Publishing. Retrieved 06-20-2010 from http://www.worldbank.org/ieg/governance/oman arndt paper.pdf.

Auty, R., and Gelb, A. (2001). Political Economy of Resource-Abundant States. In Auty, R., ed. Resource Abundance and Economic Development. New York: Oxford University Press. DOI: 10.1093/0199275785.003.0008

Badia, M and Dudine, P. (December $17^{\text {th }}$, 2019). New Data on World Debt: A Dive into Country Numbers. Retrieved 13/6/2020 from https://blogs.imf.org/2019/12/17/new-data-on-world-debt-a-dive-intocountrynumbers/\#: : :text=The\%20new\%20update\%20of\%20the,trillion\%20when\%20compared\%20to\%2 $\underline{02017 .}$

Baldacci, E., Kumar, M. (2010), Fiscal deficits, public debt, and sovereign bond yields. IMF Working Papers, 10(184), 1-28. DOI: 10.5089/9781455202188.001

Barro, R.J. (1979), On the determinants of the public debt. Journal of Political Economy, 85(5), pp. 940971. DOI: $10.1086 / 260807$

Beidas-Strom, S., \& Lorusso, M. (2019). Macroeconomic Effects of Reforms on Three Diverse Oil Exporters: Russia, Saudi Arabia, and the UK. International Monetary Fund. DOI: $10.5089 / 9781498320504.001$

Casares, E. R. (2015). A relationship between external public debt and economic growth. Estudios Económicos (México, DF), 30(2), 219-243.

Domar, E. D. (1944). The" burden of the debt" and the national income. The American Economic Review, 34(4), 798-827.

Dotsey, M. (1994), Some unpleasant supply side arithmetic. Journal of Monetary Economics, 33(3), pp. 507-524. DOI: 10.1016/0304-3932(94)90041-8

Feldstein, M. S. (1985). Debt and Taxes in the Theory of Public Finance. Journal of Public Economics 28 (1), pp. 233-245. DOI: 10.1016/0047-2727(85)90071-4 
Gaber, S. (2010). Economic implications from deficit finance (No. 69). BERG Working Paper Series on Government and Growth. Retrieved 29/2/2020 from https://fis.unibamberg.de/bitstream/uniba/1453/1/BERG No. 69 Gaberse A2b.pdf

Gale, W.G., Orszag, P.R. (2002), The Economic Effects of Long-Term Fiscal Discipline. Urban-Brookings Tax Policy Center Discussion Paper. Available from: http://www.brookings.edu/ /media/Files/rc/ papers/2002/1217taxes_gale/20021217.pdf.

Gollwitzer, S. (2010). Budget institutions and fiscal performance in Africa. Journal of African Economies, 20(1), pp. 111-152. DOI: 10.1093/jae/ejq035

Hélis, J., \& Dabán-Sánchez, D. T. (2010). A public financial management framework for ResourcesProducing Countries. International Monetary Fund (working paper WP/10/72). Retrieved 8/10/2017 from http://citeseerx.ist.psu.edu/viewdoc/download?doi=10.1.1.361.5752\&rep=rep1\&type=pdf

International Budget Partnership (IBP). (2020). Open Budget Survey-Saudi Arabia Report. Retrieved 16/6/2020 from https://www.internationalbudget.org/sites/default/files/country-surveyspdfs/2019/open-budget-survey-saudi-arabia-2019-en.pdf

International Monetary Fund (IMF). (2020a). Global Debt Database. Retrieved 13/6/2020 from https://www.imf.org/external/datamapper/datasets/GDD

International Monetary Fund (IMF). (2020b). Emergency Financing and Debt Relief. Retrieved 13/6/2020 from https://www.imf.org/en/Topics/imf-and-covid19/COVID-Lending-Tracker\#ftn

Joharji, G., \& Willoughby, J. (2014). The Saudi Arabian Budgeting System: An Institutional Assessment. Public Administration and Development, 34(1), pp. 63-80 .DOI: 10.1002/pad.1608

Kamiguchi, A., \& Tamai, T. (2019). Public investment, public debt, and population aging under the golden rule of public finance. Journal of Macroeconomics, 60 (1), pp. 110-122. DOI: 10.1016/j.jmacro.2019.01.011

Kaufmann, D., Kraay, A., \& Mastruzzi, M. (2010). The Worldwide Governance Indicators: Methodology and Analytical Issues (World Bank Policy Research Working Paper No. 5430). Washington, DC: The World Bank. DOI: $10.1017 /$ S1876404511200046

Kose, M. A., Nagle, P., Ohnsorge, F., \& Sugawara, N. (2020). Global Waves of Debt: Causes and Consequences. World Bank Publications. Retrieved 13/6/2020 from http://pubdocs.worldbank.org/en/279031577823091771/Global-Waves-of-Debt-full-report.pdf

Langbein, L., \& Knack, S. (2010). The Worldwide Governance Indicators: Six, One, or None? Journal of Development Studies; 46 (2), 350-370. DOI: 10.1080/00220380902952399

Lartey, E. Y., Musah, A., Okyere, B., \& Yusif, N. (2018). Public debt and economic growth: Evidence from Africa. International Journal of Economics and Financial Issues, 8(6), pp. 35-45. DOI: 10.32479/ijefi.7057

Mahmah, A. E., \& Kandil, M. E. (2019). The balance between fiscal consolidation and non-oil growth: The case of the UAE. Borsa Istanbul Review, 19(1), 77-93. DOI: 10.1016/j.bir.2018.05.002

Ministry of Finance- Saudi Arabia. (2020). Quarterly Budget Performance Report-Q FY 2020. Retrieved $16 / 6 / 2020$ https://www.mof.gov.sa/en/financialreport/budget2020/Documents/Q1 E 2020.pdf

from

Mirzoev, T. N., Zhu, L., Yang, Y., Zhang, T., Roos, E., Pescatori, A., \& Matsumoto, A. (2020). The Future of Oil and Fiscal Sustainability in the GCC Region (No. 20/01). Washington D.C., International Monetary Fund.

Montes, G. C., Bastos, J. C. A., \& de Oliveira, A. J. (2019). Fiscal transparency, government effectiveness and government spending efficiency: Some international evidence based on panel data approach. Economic Modelling, 79(1), pp. 211-225. DOI: 10.1016/j.econmod.2018.10.013 
Musgrave, R. A. (1959). Theory of public finance; a study in public economy. New York, NY; McGraw-Hill DOI: $10.2307 / 2227672$

Muye, I. M., Kaita, R. A., \& Hassan, A. F. S. (2017). Debt and Economic Growth in an Oil Rich Economy: Evidence from Saudi Arabia. International Journal of Economics and Financial Issues, 7(4), pp. 7075.

Najem, T. P. \& Hetherington, M., (Eds.). (2003). Good governance in the Middle East oil monarchies. Routledge.

Ncanywa, T., \& Masoga, M. M. (2018). Can public debt stimulate public investment and economic growth in South Africa?. Cogent Economics \& Finance, 6(1), pp. 1-13. DOI: $10.1080 / 23322039.2018 .1516483$

Palley, T.I. (2013). Keynesian, classical and new Keynesian approaches to fiscal policy: comparison and critique. Journal Review of Political Economy, 25(1), pp. 179-204. DOI: 10.1080/09538259.2013.775821

Pretorius, C. and Pretorius, N. (2009). Public Financial Management Reform Literature Reform. Evaluation Working Paper / Evaluation Report EV698. Retrieved 6/6/2017 from http://www.sida.se/contentassets/377f0f9cea2f409fbb0a387378e4499e/public-financialmanagement-reform-literature-review 3154.pdf

Ramady, M. (2010). The Saudi Arabian economy, policies, achievements, and challenges. (2 ${ }^{\text {nd }}$ ed.). New York, NY: Springer. DOI: 10.1007/b106381

Reinhart, C. M., \& Rogoff, K. S. (2009). This time is different: Eight centuries of financial folly. Princeton, New Jersey; Princeton university press. DOI:10.4000/histoiremesure.3997

Saint-Paul, G. (1992). Fiscal Policy in an Endogenous Growth Model, Quarterly Journal of Economics, 107(1), pp. 1243-1259. DOI: 10.2307/2118387

Saudi Arabian Monetary Authority (SAMA). (2020). Yearly Statistics. Retrieved 29/2/2020 from http://www.sama.gov.sa/en-US/EconomicReports/Pages/YearlyStatistics.aspx

Saudi Vision 2030. (2018). Financial Sector Development Program. Retrieved 12/12/2018 from https://vision2030.gov.sa/en/FSDP.

Schick, A. (1998). A contemporary approach to public expenditure management. World Bank Institute, 68(1), pp. 2-11.

Thompson, M. (2014). Saudi Arabia and the Path to Political Change: National Dialogue and Civil Society. London, U.K.; Bloomsbury Publishing. DOI: 10.1080/00263206.2014.959936

United Nations Conference on Trade and Development (UNCTD). (April 23 ${ }^{\text {rd }}$, 2020). COVID-19 is a matter of life and debt, global deal needed. Retrieved 13/6/2020 from https://unctad.org/en/pages/newsdetails.aspx?OriginalVersionID=2339

Wijeweera, A., \& Garis, T. (2009). Wagner's law and social welfare: The case of the kingdom of Saudi Arabia. Applied Econometrics and International Development, 9(2), 199-209.

Woo, J. (2009), Why do more polarized countries run more procyclical fiscal policy? Review of Economics and Statistics, 91(4), pp. 850-870. DOI: 10.1162/rest.91.4.850

World Bank (2020). Population growth (annual \%) - Middle East \& North Africa. Retrieved from: https://data.worldbank.org/indicator/SP.POP.GROW?locations=ZQ

World Bank. (2018). Worldwide Governance Indicators. Retrieved 5/15/2108 from http://info.worldbank.org/governance/wgi/\#home

World Bank. (2019). Data. Retrieved 25/5/2019 from https://data.worldbank.org/indicator/BX.KLT.DINV.WD.GD.ZS?locations=SA 
World Economic Forum. (2019). The Middle East and North Africa Risks Landscape. Retrieved 20/4/2019 from. http://www3.weforum.org/docs/WEF MENA Risks Briefing Paper.pdf.

World Economic Outlook Database (WEOD). (2020). World Economic and Financial Surveys. Retrieved 13/6/2020 from https://www.imf.org/external/pubs/ft/weo/2019/02/weodata/index.aspx

Yusuf, S., \& Said, A. O. (2018). Public Debt and Economic Growth: Evidence from Tanzania. Journal of Economics, Management and Trade, 21(7), pp. 1-12. DOI: 10.9734/JEMT/2018/41504 